\title{
The Impact of the Internal Conflicts of Brutus toward His Life in "Julius Caesar" by Shakespeare
}

\author{
Aulia Putri \\ English Department \\ University of Riau Kepulauan \\ auliaputri1983@yahoo.com
}

\begin{abstract}
The writer chose the literary work of Shakespeare entitled Julius Caesar to be analyzed. In this literature, the writer noticed that the character of Brutus who was also a friend of Julius Caesar was willing to kill his closest friend. The writer was interested in analyzing this side of Brutus. Brutus was well known as a wise and honest man but could commit a crime. Brutus did not want Rome to turn into imperial Rome which was originally a Republican state. Further, the writer analyzed the internal conflicts experienced by Brutus and its effects toward Brutus' life. In analyzing this thesis, the writer used the psychological approach with the theory of psychoanalysis; Human Psycho Zone by Sigmund Freud consisted of id, ego, and superego. The writer analyzed the internal conflicts experienced by Brutus, namely: his blindness to reality and his idealism that did not provide a benefit for him. These conflicts had negative impacts to the end of Brutus' life after killing Julius Caesar. The negative impacts in the life of Brutus namely: Brutus' wife suffered severe depression since Brutus became a murderer, Brutus felt inferior and loss his self-esteem, and destroys him. Based on the analysis conducted by the writer, the id of Brutus was more dominant than the superego. The id of Brutus dominated in any actions that Brutus did, especially for dealing with conflicts within himself.
\end{abstract}

Key Words: Internal Conflict; Human Psycho Zone; and Impact

\section{INTRODUCTION}

Generally, literature is an expression of the personality, state of mine, feeling, and desire of feeling. These ideas can be described in the medium of language, in the form of literary work, such as novel, poem, short story, drama or play. In other words, literature is one-way medium of communication between the author and the reader, so that the author can share what he thinks, feels, and experiences. A play is played by some players with certain character. There are many kinds of characters such as major character and minor character. The writer wants to analyze the internal conflict of a person, which has dynamic character. In this case she is interested in the character of Brutus in a play entitled Julius Caesar by William Shakespeare. As a result, the title of this research is: The Impacts of the Internal 
Conflicts of Brutus toward His Life in Julius Caesar by Shakespeare. The research is aimed to reveal and to analyze why the character of Brutus in Julius Caesar can kill his own friend and join the conspiracy. She wants to know the treatment of the $i d$ toward the superego of Brutus to overcome his internal conflicts and how it affects his life. In order to specify this research, the research is limited only to reveal the reasons why Brutus can kill his friend, the internal conflict that he has, and the impact toward his life. The research questions, which become the guideline of this research, are:

1. What are the internal conflicts of Brutus?

2. How the treatment of the id of Brutus toward his superego?

3. What are the impacts of the internal conflict of Brutus toward his life?

\section{MATERIALS}

In conducting this research, the writer uses the psychological approach by applying the theory of psychoanalysis "Human Psycho Zone" by Sigmund Freud. First, the writer collects the data. In collecting the data, the writer does the library research in which the data is divided into two kinds, primary and secondary data. Primary data is obtained by reading and comprehending a play entitled Julius Caesar as the source of the data. In this research, the writer uses two books entitled Julius Caesar:

1. The Arden Edition of The Works of William Shakespeare "Julius Caesar"; edited by T.S. Dorsch.

2. The Oxford and Cambridge Edition; Shakespeare's Julius Caesar by Stanley Wood, M.A.

\section{METHODS}

As a reference to take the quotations in this research, the writer uses the first book; The Arden Edition of The Works of William Shakespeare "Julius Caesar"; edited by T.S. Dorsch. After collecting the data, then the writer analyzes the data into its specification. In presenting the data, descriptive method is used since all the data consist of non-numeric data. The play consists of dialogs and uses no picture; therefore this data is represented in the form of quotations. 
In conducting this research, the writer uses objective theory. Furthermore, the writer wants to analyze the main character from psychological point of view.

Endraswara (2003:97-98) stated:

"Pada dasarnya, psikologi sastra akan ditopang oleh tiga pendekatan sekaligus. Pertama, pendekatan tekstual, yang mengkaji aspek psikologis tokoh dalam karya sastra. Kedua, pendekatan reseptif-pragmatik, yang mengkaji aspek psikologis pembaca sebagai penikmat karya sastra, serta proses resepsi pembaca dalam menikmati karya sastra. Ketiga, pendekatan ekspresif, yang mengkaji aspek psikologis sang penulis ketika melakukan proses kreatif yang terproyeksi lewat karyanya, baik penulis sebagai pribadi maupun wakil masyarakatnya."

(Basically, psychology of literature is supported by three approaches. First, textual approach, which focuses on the psychological aspects of the character in the literary work. Second, receptive-pragmatic approach, which talks about the psychological aspect of the reader as the audience of the literary work, also the process of reader's receptive in enjoying the literary work. Third, expressive approach, which talks about the psychological aspect of the author when he does the creative process which is transferred to his work, whether as a personal or represent his society.)

It depends on the writer to use which kind of approach. Since the writer focuses the analysis on the character and to the literary work itself, therefore, the writer uses the first approach or textual approach, which is suitable for her research. The writer only discusses the matters that occur in the play or the intrinsic elements. Furthermore, the focus of the analysis is the character.

In analyzing the character, the writer focuses on the main character. To see the character of the person and the reality that he has, the writer needs to see the fact from his psychology. As a result, the writer will use psychoanalysis approach by applying a theory, which is proposed by Sigmund Freud that clarifies the $i d$, the ego, and the superego.

From the book entitled A Handbook of Critical Approaches to Literature by Wilfred L. Guerin, the writer can take an understanding to Freudian theory that there are three 
psychic zones, the $i d$, the ego, and the superego. The relationship of these three is to the consciousness and unconsciousness.

The $i d$ is the reservoir of the libido, primary source of all psychic energy. The id is the source of all aggressions and desires. It is lawless, asocial, and amoral. It occurs in our mind and motivates by unconscious mind instinctively.

To protect the individual is the job of the ego. The ego is governed by the reality principle, while the $i d$ is governed by the pleasure principle. This ego regulates the instinctual drives of $i d$, so that this energy may be released in non-destructive behavior.

The last, the superego is the moral censoring agency, the repository of conscience and pride. It is an agent to evaluate the drive of $\mathrm{i} d$, avert the destructive pattern of individual and society. The superego is dominated by the morality principle.

It can be said that the id would make a person behave as devil, that the superego would have a person behave as angel, and that it remains for the ego to keep a person as a healthy human being by maintaining a balance between these two opposing forces.

\section{RESULTS AND DISCUSSION}

\section{The Internal Conflicts of Brutus}

From the story of Julius Caesar the conflict that the writer wants to analyze is the internal conflicts of Brutus. The internal conflicts of Brutus lies in him in finding the resolution when he should choose two incompatible goals in solving a problem. It is between his private needs and his public image. The problems in the play "Julius Caesar" starts when Cassius and friends feel afraid toward Caesar's position. They assume that Caesar will begin to admit himself as a King, the new power in Rome. There will be no more Republicanism. Caesarism is begun to arise. That is also the first time for Brutus to have the same problem. He feels the same with Cassius and friends. He starts to think this matter deeply. It is true that Julius Caesar is in his highest position ever. He gains the power from the Roman people. Everybody loves him, adores him as the mightiest. In the other side, some people-including Brutus, begin to observe the situation, predict what may come, and try to prevent it earlier. Brutus has conflicts in the process of observing. These conflicts pure happen in his mind and 
in his heart. He deals with men and country. Friendship or duty? These are two questions that lie in all matters.

Before seeing the internal conflicts of Brutus, the writer first analyzes the id that Brutus has. According to Freudian Theory, the $i d$ presents at birth. It consists of such basic needs, which Freud called the life instinct, fuelled by a form of energy called the libido. The id also contains a death instinct, responsible for aggressiveness and destruction. The id operates on the pleasure principle, which demands immediate gratification no matter what. This part of personality of human beings happens to Brutus. The writer sees how the treatment of the $i d$ toward the superego of Brutus in the record of his life. The function of superego is to divert the ego from its realistic approach to a moralistic orientation. The superego is the opposite of the $i d$ and the ego. When the ego postpones instinctual gratification; the superego tries to block it permanently. In the case of Brutus, the id more controls the personality rather than the superego. There are two points that Brutus has as the act of his ' $i d$ '. They are 'the $i d$ versus the superego of Brutus in seeing the reality' and 'the $i d$ versus the superego of Brutus in his idealism'. Furthermore, the writer analyzes them one by one.

\section{The Id versus the Superego of Brutus in Seeing the Reality}

In Julius Caesar, the personality of Brutus is known as noble, wise, valiant, and honest. This is proved by the speech of a servant in his point of view toward Brutus:

Serv. $\quad$ Thus he bade me say:

Brutus is noble, wise, valiant, and honest;

Caesar was mighty, bold, royal, and loving.

Say I love Brutus, and I honour him.

Say I fear'd Caesar, honour'd him, and lov'd him.

(Act III, Scene i, 126-129) 
From the previous quotation, it is see that a servant loves the two influencing-people in Rome-Brutus and Julius Caesar. It is not only Caesar that has Roman's heart but Brutus as well. As he is a noble, wise, valiant, and honest in nature, the people love him in his patriotism, his idealism, his gentleness, and his philosophy. These characteristics of Brutus are categorized as Brutus' superego but, beyond that, his personality is trapped in the problem. It is the time when his id controls his superego. Brutus cannot see the reality. As a result, he does not find a good solution to solve the further problem, which may come. He fears that Caesar will be crowned and legitimated as a King. As the story tells that Rome is Republic country not a monarchy. So when a man-Julius Caesar dominates the absolute power in Rome, the victory of Rome will vanish. No more freedom and liberty as Brutus hates on a tyranny. His anxiety is described in his soliloquy as follows:

Bru. It must be by his death: and for my part,

I know no personal cause to spurn at him,

But for the general. He would be crown'd:

How that might change his nature, there's the question.

It is the bright day that brings forth the adder,

And that craves wary walking. Crown him?-that; --

And then, I grant, we put a sting in him,

That at his will he may do danger with.

Th' abuse of greatness is when it disjoins

Remorse from power; and, to speak truth of Caesar,

I have not known when his affections sway'd

More than his reason. But 'tis a common proof,

That lowliness is young ambition's ladder,

Whereto the climber-upward turns his face; 
But when he once attains the upmost round,

He then unto the ladder turns his back,

Looks in the clouds, scorning the base degrees

By which he did ascend. So Caesar may;

Then lest he may, prevent. And since the quarrel

Will bear no colour for the thing he is,

Fashion it thus: that what he is, augmented,

Would run to these and these extremities;

And therefore think him as a serpent's egg,

Which, hatch'd would, as his kind, grow mischievous,

And kill him in the shell.

(Act II, Scene i, 10-34)

From the above quotation of soliloquy, the writer analyzes that Brutus is concerned about the position of Caesar that will lead Rome to deterioration. His blindness to reality is obviously seen, as he is known as a close friend to Caesar means that he should know the natures of his friend. Is it true that Caesar is a danger to the country or not? Why does Brutus can be easily influenced by others about the threat? His blindness is as the fact of the $i d$ that controls his mind. His superego, which should open his mind clearly about the possible chance in Caesar to be the King, is covered by the $i d$. As a result, Brutus could not think wisely about his close friend. In other words, Brutus jumps into conclusion.

\section{The Id versus the Superego of Brutus in His Idealism}

The second role of the id in Brutus is his ineffectual idealism. It is ineffectual since he made a right perception in his first thought but wrong in conclusion. This is about his joining 
in the conspiracy, about the motive that he has beyond it. He thinks that to safe Rome, he should kill Caesar who is indeed his close friend. His choice is described as follows:

Bru.

Not that I loved Caesar less, but that I loved Rome more.

(Act III, Scene ii, 22-23)

Knowing as a patriotic, Brutus will do anything to his beloved country-Rome. But he forgets something that the good cannot come out of evil. Though his reason in killing Caesar is lofty, but still it cannot be said that murdering someone for a good thing is a good deed. His idealism makes him controlled by his $i d$ rather than his superego in seeing another better solution and still in morality. This can be seen in the descriptions that the writer will give further.

After deciding to join the conspirators, Brutus held a meeting in his house in the middle of the night. It is almost dawn. When Cassius suggests that they all take an oath to swear their loyalty to the assassination, Brutus refuses. This is described in the quotation below:

Cas. And let us swear our resolution.

Bru. No, Not an oath. If not the face of men,

The sufferance of our souls, the time's abuse-

If these be motives weak, break off betimes,

And every man hence to his idle bed.

(Act II, Scene i, 113-117)

Furthermore, Brutus said that as a Roman they have no need to do the oath because without it too there still do it for Rome. For the reason, Brutus is a noble character, but in the other side, killing somebody is a bad deed no matter what the reason is. Brutus once again trapped in his wrong perception in reaching for everybody's good. 


\section{The Impacts of Internal Conflicts of Brutus toward His Life}

\section{The Depression of Brutus’ Wife}

Having choosing to join the conspirator, Brutus has let himself to several disadvantages in his life. This is as the treatment of the id toward the superego of Brutus. Since he thinks he does the conspiracy for Roman's good, he acts like an 'unusual' Brutus. A wife to Brutus-Portia, notice Brutus‘ change.

Por. Brutus, my lord.

Bru. Portia, what mean you? Wherefore rise you now?

It is not for your health thus to commit.

Your weak condition to the raw cold morning.

Por. Nor, for yours neither. Y'have ungently, Brutus,

Stole from my bed, and yesternight at supper

You suddenly arose, and walk'd about,

Musing, and sighing, with your arms across;

And when I ask'd you further; then you scratch'd your head.

I urg'd you further; then you scratch'd your head.

(Act II, Scene i, 233-243)

From the speech of Portia, it shows that Brutus has changed his attitude toward his wife, whether he realizes it or not. Next dialog strengthens the difference in Brutus' behaviour:

Por.

I should not know you Brutus. Dear my lord,

Make me acquainted with your cause of grief

Bru. I am not well in health, and that is all. 
Por. Brutus is wise, and, were he not in health,

He would embrace the means to come by it.

Bru. Why, so I do. Good Portia, go to bed.

(Act II, Scene i, 255-260)

It is seen from the above quotation that Brutus cannot hide his internal conflict to his wife, Portia. This makes a little stain in their relationship. Brutus cannot handle his id although he is a good philosopher. The fact that his philosophy makes him trapped in his own belief. His superego is covered by his $i d$, so he cannot see the problems clearer. Although Brutus trusts his wife-Portia, still he cannot tell her the secret or the will that he is willing to do. He does not want to worry Portia.

Bru. You are my true and honourable wife,

As dear to me as are the ruddy drops

That visit my sad heart.

Por. If this were true, then should I know this secret.

I grant I am a woman; but withal

A woman that Lord Brutus took to wife;

I grant I am a woman; but withal

A woman well reputed, Cato's daughter.

Think you I am no stronger than my sex,

Being so father'd and so husbanded?

(Act II, Scene i, 288-297)

Portia is a good wife to Brutus. She is loving, caring, and understanding, but Brutus does not want her wife to get trouble to what he has now. Desperately trying in convincing Brutus to trust her, Portia still wants to help her husband and worry her Husband's internal 
conflict. She sends Lucius to find out what the matters that might happen are or what the secret or the plan that her husband hides from her.

Por. I prithee, boy, run to the Senate House.

Stay not to answer me, but get thee gone.

Why dost thou stay?

Luc. To know my errand, madam.

Por. I would have had thee there and here again

Ere I can tell thee what thou should'st do there.

O constancy, be strong upon my side;

Set a huge mountain 'tween my heart and tongue!

I have a man's mind, but a woman's might.

How hard it is for women to keep counsel!

Art thou here yet?

(Act II, Scene iv, 1-9)

Portia is dying in worrying her husband. She cannot hold the reality by herself that her husband has killed his own-true friend, Caesar. Portia's depression is also described in the dialogs below:

Bru. O Cassius, I am sick of many griefs.

Cas. Of your philosophy you make no use,

If you give place to accidental evils.

Bru. No man bears sorrow better. Portia is dead.

Cas. Ha? Portia?

Bru. She is dead.

Cas. How 'scap'd killing, when I cross'd you so? 
O, insupportable and touching loss!

Upon what sickness?

(Act IV, Scene iii, 143-151)

The above dialog describes that Portia dies because she cannot accept the reality that she has. Knowing her husband is a murderer becomes a heavy burden in her mind. Next dialogs show how Brutus feels depressed in losing her wife.

\section{The Inferiority of Brutus}

After stabbing Caesar, Brutus gives his explanation why he kills Caesar. They arrange the deed in order to free Rome from an ambitious leader. Rome will lead to its decay if they let Caesar become the King. In the funeral's oration, Brutus gives time to Antony to give his words about Caesar to the Romans as Brutus permits him. It is the threat for the conspirators as Cassius tells before, that Antony will provoke the mass to take revenge for Caesar's death. Then the following:

Ant. Friends, Romans, countrymen, lend me your ears;

I come to bury Caesar, not to praise him.

The evil that men do lives after them,

The good is oft interred with their bones;

So let it be with Caesar. The noble Brutus

Hath told you Caesar was ambitious.

If it were so, it was a grievous fault,

And grievously hath Caesar answer'd it.

Here, under leave of Brutus and the rest,

(For Brutus is an honourable men) 
Come I to speak in Caesar's funeral.

(Act III, Scene ii, 75-84)

Antony gives his best shot in influencing the mass. The way he uses is so smooth and easy going. Furthermore he adds:

Ant.

He was my friend, faithful and just to me;

But Brutus says he was ambitious,

And Brutus is an honourable man

He hath brought many captives home to Rome,

Whose ransoms did the general coffers fill:

Did this in Caesar seem ambitious?

When that the poor have cried, Caesar hath wept;

Ambition should be made of sterner stuff:

Yet Brutus says he was ambitious,

And Brutus is an honourable man.

(Act III, Scene ii, 85-94)

The above description shows us that Brutus is controlled by his $i d$. He is too naive by saying that the stabbing of Caesar is for Roman's goodness. In this part, his id controls his mind. It affects his superego, which the superego cannot see clearer to the situation of the country. As a result, the ego precedes nothing. 


\section{Brutus' Self-destruction}

After losing his wife and regretting his deed, Brutus feels that his life means nothing now. He is no longer proud to be a Roman. He himself now is not eager to continue his life. Instead of seeing the future that he will be killed by the Roman who wants to take revenge after him, Brutus finds out another way. It is a way that he thinks he would not die as a looser which means not die killing by other. He decides to end up his own life by stabbing his body with the dagger he stabs Caesar. This part of taking conclusion in his mind shows that the treatment of his $i d$ toward his superego is so strong that the superego cannot tell Brutus that killing himself is a foolish way. This motion describes as follows:

Bru.

I know my hour is come.

Vol. Not so, my lord.

Bru. Nay, I am sure it is, Volumnis.

(Act V, Scene v, 19-21)

Bru.

Hold then my sword, and turn away thy face,

While I do run upon it. Wilt thou, Strato?

Stra. Give me your hand first. Fare you well, my lord.

Bru. Farewell, good Strato. -Caesar, now be still;

I kill'd not thee with half so good a will.

[Dies.]

(Act V, Scene V, 47-51)

By deciding to commit suicide, Brutus pronounces himself dead in honour not as a people who seek by the Romans like an escape prisoner. This action is his last wrong interpretation to his life. He once again let himself controlled by the $i d$ by pretending that killing himself is for his own goodness. His superego is vanished by the id. He lets himself to 
do self-destruction. Brutus has lost his moral value to his own life though he thinks that his stabbing of Caesar is for general's goodness. His private self has defeated by his public image.

From the above explanations, Brutus' superego such as doing the right thing for the right purpose has been covered by his instinctive id that he can do whatever to overcome every problem. He naively cannot see that goodness cannot come out of evil, that doing murder for good reason is not good. His superego as the part of his personality has been wrinkled by the $i d$. Brutus is as the victim of his own wrong decision in interpreting the situation of the problem.

\section{CONCLUSION}

Brutus is one of the conspirators that have a reason. Killing Caesar is for Roman's goodness. He is one of the senators and one of the powerful people in Rome. He is also a close friend of Julius Caesar. He has internal conflicts when he had to choose between friendship and duty. Brutus' internal conflicts described in his id versus his superego in seeing the reality and in his id versus his superego in his idealism. He is misleading in achieving his thought about the deed to kill Caesar. His reason is true, but the resolution is wrong. In fact, he chooses to kill Caesar because he thinks that he does it for his countryRome. This is as the fact that his id controls his superego. The treatment of the id to his superego is so strong that he cannot see the problems and the effects or the impacts clearer.

Doing the stabbing to Caesar has caused several impacts to Brutus' life. First, the depression of Brutus' wife, who cannot endure the fact about his husband killing Caesar. Because Brutus left her in the city, she died desperately. Second, the inferiority of Brutus, Brutus loses his pride. This happens when Antony gives his funeral's oration, which moves the mass to take revenge to the murderers of Caesar, including Brutus. The last is Brutus' self-destruction. He ruins his life as he regrets what he has done to Roman people. He has lost his wife, his pride. So he feels nothing left to be proud of. Then he decides to do suicide. So he can die in honour. By that time, death in someone's hand is embarrassed, but death in own hand is honoured. Brutus has let himself controlled by his death instinct which gets the energy from Brutus' id. 
The impacts that Brutus has in his life is because he does a wrong deed. Although his reason is good and honor, but the final action is fatally wrong. Good cannot come out of evil. His character, which is noble, wise, valiant, and honest, is trapped in his last action in his life. But people saved him as the one who does it for Roman's goodness, the other conspirators are vile. Although people memorized him this way, but Brutus has lived in regrets, desperate, and feels useless. He has controlled by his own thought that led him to his death. This is the action of his id toward his superego. The treatment of Brutus' $i d$ is so strong for the superego to overcome Brutus' internal conflicts and to find the best resolution. Brutus' superego fails to handle Brutus' id.

\section{REFERENCES}

DiYanni, Robert. Literature: Reading Fiction, Poetry, and Drama: Part One; Fiction. Boston

Dorsch, T.S. . The Arden Edition of the Work of William Shakespeare; Julius Caesar. Routledge: London

Endraswara, Suwandi. 2003. Metodologi Penelitian Sastra. Yogyakarta: FBS University Negeri Yogyakarta. 